\title{
Effects of Ethanol-Gasoline Blends, Compression Ratio and Cylinder Head Material on Engine
}

\author{
Carlos A. Romero, Ph.D. ${ }^{1}$, Yamid A. Carranza, MSc. ${ }^{1}$, and Luz Adriana Mejía, MSc. ${ }^{1}$ \\ ${ }^{1}$ Universidad Tecnológica de Pereira, Colombia, cromero@utp.edu.co, yamidc@utp.edu.co, adriamec@utp.edu.co
}

\begin{abstract}
A Design of experiments methodology was carried out to investigate the effects of the compression ratio, cylinder head material, and fuel composition, on the engine speed, fuel consumption, warm-up time, and emissions of a carbureted single cylinder air-cooled spark ignited engine. The work presented here is aimed at finding out the sensitivity of engine responses, as well as the optimal combination between the abovementioned parameters. Engine performance was evaluated based on the changes in engine speed at idle conditions. Regarding the exhaust gas emissions, the concentrations of $\mathrm{CO} 2, \mathrm{CO}$, and $\mathrm{HC}$ were recorded.
\end{abstract}

Keywords - Combustion engine, ethanol-gasoline blends, compression ratio, material, warm-up

Digital Object Identifier (DOI): http://dx.doi.org/10.18687/LACCEI2015.1.1.266

ISBN: 13 978-0-9822896-8-6

ISSN: $2414-6668$

13 $^{\text {th }}$ LACCEI Annual International Conference: “Engineering Education Facing the Grand Challenges, What Are We Doing?” July 29-31, 2015, Santo Domingo, Dominican Republic DOI: http://dx.doi.org/10.18687/LACCEI2015.1.1.266 


\title{
Effects of ethanol-gasoline blends, compression ratio and cylinder head material on engine
}

\author{
Carlos A. Romero, Ph.D ${ }^{1}$, Yamid A. Carranza, $\mathrm{MSc}^{1}$, and Luz Adriana Mejía, MSc ${ }^{1}$ \\ ${ }^{1}$ Universidad Tecnológica de Pereira, Colombia, cromero@utp.edu.co, yamidc@utp.edu.co, adriamec@utp.edu.co
}

\begin{abstract}
A Design of experiments methodology was carried out to investigate the effects of the compression ratio, cylinder head material, and fuel composition, on the engine speed, fuel consumption, warm-up time, and emissions of a carbureted single cylinder air-cooled spark ignited engine. The work presented here is aimed at finding out the sensitivity of engine responses, as well as the optimal combination between the abovementioned parameters. Engine performance was evaluated based on the changes in engine speed at idle conditions. Regarding the exhaust gas emissions, the concentrations of $\mathrm{CO} 2, \mathrm{CO}$, and $\mathrm{HC}$ were recorded.

Keywords-- Combustion engine, ethanol-gasoline blends, compression ratio, material, warm-up
\end{abstract}

\section{INTRODUCTION}

Measures for reducing the reliance dependency on fossilfuels for combustión engines include improving efficiency and substitution of gasoline with alternative fuels. Among these, ethanol is one of the most extensively used all over the world because of its high-octane, high combustion speed, and clean-burning.

The literature related to the performance assessment of SI automotive engine fed with ethanol-gasoline blends is abundant. However, most of the studies relate to automotive engines, while it is scarce the information related to the influence of the ethanol-gasoline composition on the performance of small non-road engines, those used in household and commercial applications, including lawn and garden equipment, utility vehicles, generators, and a variety of other construction, farm, and industrial equipment [3, 4]. Nonroad gasoline engines differ from automotive engines in several technical specifications, and are very sensitive to the gasoline calibration. Because of these design differences, it is supposed that the effects of ethanol-gasoline blended fuel changes on performance and emission characteristics from non-road gasoline engines are quite different from the effects of ethanol-gasoline blended fuel changes on performance and emissions from automotive gasoline engines.

The sensitivity of the engine to the fuel composition depends also on the engine service life: the combustion chamber deposits (CCD) diminish the engine heat rejection (the conductivity of the engine walls decreases); the wearing process of the engine may lead to a reduction in the compression ratio. This is why in the present study it has been attempted a design of experiments methodology intended to evaluate the sensitivity of the engine warm-up time, performance, and emissions to the change in the fuel composition, the thermal wall properties, and the compression ratio. To simulate the reduced conductivity of the combustion chamber walls, for the cylinder head of the engine two materials, aluminum and cast iron, have been considered. To simulate the reduction of the compression ratio, a screwed cylinder has been placed in the spark plug location, augmenting the combustion chamber volume. The experiments are carried out based on the engine speed increase being calibrated for the baseline engine. The data collection is done during warm-ups and also at idle conditions.

The paper here presented is a report of the first steps made under a research in progress, and relates mainly to the performance of the engine at idle conditions. In the following parts of this document a brief description of the experimental set-up will be explained. Then it is given a brief explanation of the measuring methodology. In the third part of the paper results of the experiments are analyzed. Conclusions derived from the work close the paper.

\section{EXPERIMENTAL SET UP}

During idle and warm-up operating conditions, most of the SI engines run on rich mixtures, which cause incomplete combustion, and $\mathrm{CO}$ and unburned $\mathrm{HC}$ emissions increase [13]. Favourable factors for reducing these emissions are the increase of compression ratio, the reduction of heat losses, and the induction of oxygenated gasolines. Thus, the aim of this work has been the evaluation of cylinder head material (cast iron, a less conductive material as compared to aluminum), compression ratio, and fuel composition on engine warm-up, performance and emissions at idle conditions, by the realization of an experimental design of experiment (DOE) plan. Besides the fuel supply with two fuels, the requirements to be met by the installation needed to perform the study here presented, were threefold. In the first place the engine had to allow an easy randomly selected removal and assembly of the aluminum or cast iron cylinder heads. In the second place a simple design of the means to change the compression ratio of the engine had to be considered. In the third place, the installation had to incorporate the instrumentation to measure the engine speed, fuel consumption, temperatures, and emissions.

\section{A. Test engine}

The engine used to perform the experiment was a singlecylinder ROBIN EY 15D of $143 \mathrm{~cm} 3$ swept volume. It is actually a good representative of the "utility engines" group (EPA's classification for non hand held equipment). This is a

$1^{\text {th }}$ LACCEI Annual International Conference: “Engineering Education Facing the Grand Challenges, What Are We Doing?” July 29-31, 2015, Santo Domingo, Dominican Republic ISBN: 13 978-0-9822896-8-6 ISSN: 2414-6668 
typical small engine found in some yard machine applications and also in pump and compressor sets.

\section{B. The cast iron cylinder head References}

To simulate the reduction of heat transfer from the cylinder walls, a cylinder head made of cast iron was fabricated, preserving the integrity of the original design. The thermal conductivity of the cast iron is approximately three times lower than that of aluminum.

\section{Change in the compression ratio}

The solution proposed here to change the compression ratio is similar to those used in stratified charge engines. The insert is shaped in a form of the hollow cylinder. Such solution, with no moving parts, does not require major changes in cylinder head and consequently is more adaptable to the baseline engine. With the adapter, the original compression ratio 7,2 is reduced to 6,6 in the modified engine. The value from 7,2 to 6,6 is representative of a used worn out engine.

\section{Test fuels}

Ideally, an engine would be optimized for its fuel. In the case of the non-road engine, however, it is not easy to take full advantages of the properties of ethanol, simply because the engine has to compromise for operations on gasoline. The ethanol-gasoline mixtures that were used in this work were E10 and E20. The "E" refers to ethanol by volume in the blend, and the " 10 " refers to $10 \%$ ethanol, $90 \%$ gasoline. For the preparation of the mixtures, the automotive gasoline was used along with ethyl alcohol of 99,7 \% purity [13]. Mixtures were prepared on a daily basis so that any possibility of content change due to evaporation or atmospheric humidity was minimized. The properties of the fuels used are shown in Table I.

TABLE I

PROPERTIES OF ETHANOL-GASOLINE BLENDS [13]

\begin{tabular}{|c|c|c|c|c|c|c|}
\hline \multicolumn{2}{|c|}{ Quality parameter } & $\begin{array}{c}\text { Test } \\
\text { method }\end{array}$ & Units & $\begin{array}{c}\text { Base } \\
\text { gasoline }\end{array}$ & $\begin{array}{c}\text { Bio- } \\
\text { gasoline } \\
\text { E10 }\end{array}$ & $\begin{array}{c}\text { Bio- } \\
\text { gasoline } \\
\text { E20 }\end{array}$ \\
\hline \multicolumn{2}{|c|}{ Ethanol content } & $\begin{array}{l}\text { ASTM } \\
\text { D5501 }\end{array}$ & $\begin{array}{c}\% \\
\text { vol. }\end{array}$ & 7,7 & 12,3 & 22,3 \\
\hline \multirow{4}{*}{$\begin{array}{l}\text { Disti- } \\
\text { lation } \\
\text { range }\end{array}$} & $\begin{array}{l}10 \% \\
\text { evapo }\end{array}$ & \multirow{4}{*}{$\begin{array}{c}\text { ASTM } \\
\text { D86 }\end{array}$} & ${ }^{\circ} \mathrm{C}$ & 51,8 & 52,3 & 53,4 \\
\hline & $\begin{array}{l}50 \% \\
\text { evapo }\end{array}$ & & ${ }^{\circ} \mathrm{C}$ & 87,9 & 69,1 & 70,8 \\
\hline & $\begin{array}{l}90 \% \\
\text { evapo }\end{array}$ & & ${ }^{\circ} \mathrm{C}$ & 161,4 & 159,3 & 154,9 \\
\hline & $\begin{array}{c}\text { Final } \\
\text { boiling } \\
\text { point }\end{array}$ & & ${ }^{\circ} \mathrm{C}$ & 217,3 & 206 & 201,2 \\
\hline \multicolumn{2}{|c|}{ Water content } & $\begin{array}{c}\text { ASTM } \\
\text { E203 }\end{array}$ & $\begin{array}{c}\% \\
\text { vol. }\end{array}$ & 0,061 & 0,087 & 0,136 \\
\hline \multicolumn{2}{|c|}{$\begin{array}{l}\text { Reid vapor } \\
\text { pressure }\end{array}$} & $\begin{array}{l}\text { ASTM } \\
\text { D323 }\end{array}$ & psi & 8,8 & 8,7 & 8,4 \\
\hline \multicolumn{2}{|c|}{ Heating value } & $\begin{array}{l}\text { ASTM } \\
\text { D3338 }\end{array}$ & $\mathrm{MJ} / \mathrm{kg}$ & & 45,86 & 44,8 \\
\hline \multicolumn{2}{|c|}{$\begin{array}{l}\text { Research octane } \\
\text { number }\end{array}$} & $\begin{array}{l}\text { ASTM } \\
\text { D2699 }\end{array}$ & RON & 89 & 90,9 & 95 \\
\hline
\end{tabular}

\section{E. Measuring Equipment}

A LEXUS balance, accurate to $0,5 \mathrm{~g}$, and a $300 \mathrm{ml}$ separating funnel were used to measure the fuel consumption; exhaust gases were sampled from the outlet and the $\mathrm{CO}, \mathrm{CO} 2$, and $\mathrm{HC}$ emissions were measured with a QRO-401 gas analyzer; the engine speed was measured by means of a SKF serie TMRT contact tachometer; the engine temperatures were measured using FLUKE 54 II digital thermometer and two Ktype thermocouples. Compression pressure of the engine was measured with a Milton compression meter. An illustration of the experimental setup is shown in Figure 1.

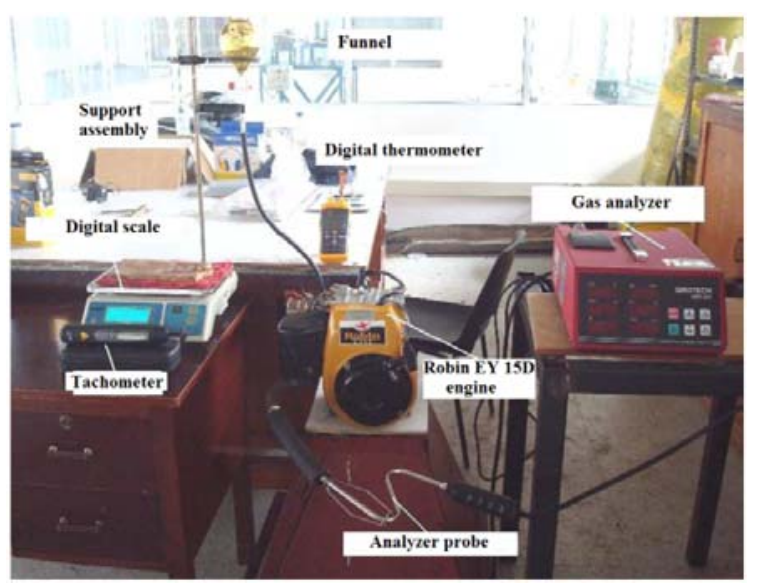

Fig. 1 Experimental test stand.

\section{EXPERIMENTAL DESIGN}

The installation described above was used to investigate the influence of the cylinder head material, fuel composition, and compression ratio on the warm-up time, engine performance, and emissions of the small gasoline engine. The performance of the engine is assessed based on the engine speed changes, initially calibrated for the baseline engine.

TABLE II FACTORIAL DESIGN OF THE EXPERIMENT

\begin{tabular}{|c|c|c|c|}
\hline \multicolumn{4}{|c}{ FACTORIAL DESIGN OF THE EXPERIMENT } \\
\hline Test $\mathrm{N}^{\circ}$ & Material & $\begin{array}{c}\text { Compression } \\
\text { ratio, } \varepsilon\end{array}$ & $\begin{array}{c}\text { Ethanol-gasoline fuel } \\
\text { blend }\end{array}$ \\
\hline 1 & -1, Aluminum & $1,6,6$ & $1, \mathrm{E} 10(90 / 10)$ \\
\hline 2 & -1, Aluminum & $1,6,6$ & $-1, \mathrm{E} 20(80 / 20)$ \\
\hline 3 & 1, Cast iron & $-1,7,2$ & $1, \mathrm{E} 10(90 / 10)$ \\
\hline 4 & 1, Cast iron & $1,6,6$ & $1, \mathrm{E} 10(90 / 10)$ \\
\hline 5 & -1, Aluminum & $-1,7,2$ & $-1, \mathrm{E} 20(80 / 20)$ \\
\hline 6 & 1, Cast iron & $-1,7,2$ & $-1, \mathrm{E} 20(80 / 20)$ \\
\hline 7 & 1, Cast iron & $1,6,6$ & $-1, \mathrm{E} 20(80 / 20)$ \\
\hline 8 & -1, Aluminum & $-1,7,2$ & $1, \mathrm{E} 10(90 / 10)$ \\
\hline
\end{tabular}

For the examination of the sensitivity of the global engine performance to the changes in engine walls conductivity (a change of the cylinder head material), compression ratio, and ethanol-gasoline mixture composition, a screening methodology was chosen. Selection of the values for the parameters of the factorial experimental design was based on a practical approach. Engine tests were performed without any

$1^{\text {th }}$ LACCEI Annual International Conference: "Engineering Education Facing the Grand Challenges, What Are We Doing?" July 29-31, 2015, Santo Domingo, Dominican Republic 
engine modification (baseline) or engine settings, irrespective of the parameters change. The full factorial design was performed ( 8 tests) as described in Table II.

\section{RESULTS AND ANALYSIS}

A summary of the processed results of 8 runs performed for each of the tests, are presented in Table III.
The statistical analysis of the results was performed, taking each response variable as a function of the varied factors. The analysis included analysis of variance table (ANOVA), Pareto chart, means plots, and response surfaces, but given the room available in this publication only a brief (not detailed) description of the results is presented, highliting the response of the warm-up time. For all pertinent tests significance was determined using a 0,05 p-value.

TABLE III

TEST RESULTS

\begin{tabular}{|c|c|c|c|c|c|c|c|c|}
\hline Test $\mathrm{N}^{\mathrm{o}}$ & Material & Compression ratio, $\varepsilon$ & Fuel blend & $\begin{array}{c}\text { Fuel consumption, } \\
\mathrm{ml} / \text { cycle }\end{array}$ & $\mathrm{CO}, \%$ & $\mathrm{CO}_{2}, \%$ & $\mathrm{HC}, \mathrm{ppm}$ & $\mathrm{RPM}, \min ^{-1}$ \\
\hline 1 & $-1, \mathrm{Al}$ & $1,6,6$ & $1, \mathrm{E} 10$ & 0,004976 & 0,36 & 5,15 & 2844 & 1651,5 \\
\hline 2 & $-1, \mathrm{Al}$ & $1,6,6$ & -1, E20 & 0,005243 & 0,19 & 5,10 & 3353,67 & 1576,7 \\
\hline 3 & $1, \mathrm{CI}$ & $-1,7,2$ & $1, \mathrm{E} 10$ & 0,004601 & 4,44 & 10,87 & 1698,67 & 2079,8 \\
\hline 4 & $1, \mathrm{CI}$ & $1,6,6$ & $1, \mathrm{E} 10$ & 0,004628 & 1,25 & 8,30 & 4603,50 & 1494,8 \\
\hline 5 & $-1, \mathrm{Al}$ & $-1,7,2$ & -1, E20 & 0,004225 & 0,62 & 12,20 & 1882,67 & 1920,5 \\
\hline 6 & $1, \mathrm{CI}$ & $-1,7,2$ & -1, E20 & 0,004096 & 1,79 & 11,57 & 2263,50 & 1931 \\
\hline 7 & $1, \mathrm{CI}$ & $1,6,6$ & -1, E20 & 0,005022 & 0,51 & 8,05 & 4714,67 & 1487,7 \\
\hline 8 & $-1, \mathrm{Al}$ & $-1,7,2$ & $1, \mathrm{E} 10$ & 0,004061 & 1,45 & 12,37 & 1564,17 & 2083 \\
\hline
\end{tabular}

A. Fuel consumption analysis

The analysis of variance for fuel consumption is summarized in Table IV.

TABLE IV

FACTORIAL DESIGN OF THE EXPERIMENT

\begin{tabular}{|l|c|c|c|c|c|}
\hline & $\begin{array}{c}\text { Sum of } \\
\text { Squares }\end{array}$ & $\begin{array}{c}\mathrm{D} \\
\mathrm{oF}\end{array}$ & $\begin{array}{c}\text { Mean } \\
\text { Squares }\end{array}$ & $\begin{array}{c}\text { F- } \\
\text { Ratio }\end{array}$ & $\begin{array}{c}\text { P- } \\
\text { Value }\end{array}$ \\
\hline A:Material & $3,10866 \mathrm{e}-9$ & 1 & $3,10866 \mathrm{e}-9$ & 0,04 & 0,8755 \\
\hline B: CR & $1,04264 \mathrm{e}-6$ & 1 & $1,04264 \mathrm{e}-6$ & 13,15 & 0,1713 \\
\hline $\begin{array}{l}\text { C:Flue } \\
\text { blend }\end{array}$ & $1,28721 \mathrm{e}-8$ & 1 & $1,28721 \mathrm{e}-8$ & 0,16 & 0,7561 \\
\hline AB & $1,20222 \mathrm{e}-7$ & 1 & $1,20222 \mathrm{e}-7$ & 1,52 & 0,4342 \\
\hline AC & $3,65446 \mathrm{e}-8$ & 1 & $3,65446 \mathrm{e}-8$ & 0,46 & 0,6203 \\
\hline BC & $1,25776 \mathrm{e}-7$ & 1 & $1,25776 \mathrm{e}-7$ & 1,59 & 0,4272 \\
\hline Total Error & $7,92617 \mathrm{e}-8$ & 1 & $7,92617 \mathrm{e}-8$ & & \\
\hline
\end{tabular}

The results show that there were no significant differences due to any of the studied factors, so neither was their interactions, though fuel consumption did experience a very slight but not statistically significant difference with compression ratio for the values comprised within the interval studied, and under idle engine operation. The relative importance of the controlled factors on fuel consumption was followed in the Pareto Chart, where compression ratio stood out. The maximum fuel consumption per cycle $(0,00534314$ $\mathrm{ml} /$ cycle ) corresponds to the aluminum cylinder head, with the 6,66 value for compression ratio, and the E20 fuel blend. The minimum fuel consumption per cycle $(0,00412516$ $\mathrm{ml} /$ cycle) takes place with the aluminum cylinder head, a compression ratio of 7,2, and the E20 fuel blend. From the steepness of the surface response, it was concluded a solid trend in the influence of compression ratio on cycle fuel consumption, which decreases almost linearly with the compression ratio increase.

\section{B. Fuel consumption analysis}

Table V summarizes the analysis of variance for engine speed. There are no significant differences due to cylinder head material and fuel blend, though engine speed does experience a statistically significant difference with compression ratio. The Pareto chart supported this conclusion.

TABLE V

ANALYSIS OF VARIANCE FOR ENGINE SPEED

\begin{tabular}{|l|c|c|c|c|c|}
\hline & $\begin{array}{c}\text { Sum of } \\
\text { Squares }\end{array}$ & DoF & $\begin{array}{c}\text { Mean } \\
\text { Squares }\end{array}$ & F-Ratio & $\begin{array}{c}\text { P- } \\
\text { Value }\end{array}$ \\
\hline A:Material & 7100,74 & 1 & 7100,74 & 19,48 & 0,1418 \\
\hline B: CR & 406649,0 & 1 & 406649,0 & $\begin{array}{c}1115,6 \\
3\end{array}$ & 0,0191 \\
\hline $\begin{array}{l}\text { C:Flue } \\
\text { blend }\end{array}$ & 19337,6 & 1 & 19337,6 & 53,05 & 0,0869 \\
\hline AB & 8001,13 & 1 & 8001,13 & 21,95 & 0,1339 \\
\hline AC & 827,024 & 1 & 827,024 & 2,27 & 0,3731 \\
\hline BC & 6574,6 & 1 & 6574,6 & 18,04 & 0,1472 \\
\hline Total Error & 364,5 & 1 & 364,5 & & \\
\hline
\end{tabular}

Means plots of engine speed are illustrated in Figure 2. While it is difficult to detect a significant difference between materials, the engine speed mean is greater with the 7,2 than with the 6,6 compression ratio value, the engine speed increase is around $22,5 \%$. The ethanol content change in the mixture has also a slight influence, though not as significant as the compression ratio has. It is higher in general the engine speed for the E10 fuel blend as compared to E20, what can partially be explained by its higher heating value.

The two separate response surfaces depicted in Figure 3 provide visual interpretation of factor effects on engine speed as a function of compression ratio and fuel composition for fixed cylinder head materials, aluminum and cast iron. From these graphics, it is clear that engine speed increases linearly with the compression ratio increase, and the reduction of

13 $^{\text {th }}$ LACCEI Annual International Conference: "Engineering Education Facing the Grand Challenges, What Are We Doing?" July 29-31, 2015, Santo Domingo, Dominican Republic 
ethanol in the fuel content. The higher engine speed, 2089,75 min-1, takes place for a combination of aluminum material, 7,2 compression ratio, and E10 fuel blend. The lower engine speed, 1480,92 min-1, occur with a combination of cast iron material, 6,6 compression ratio, and E20 fuel blend.
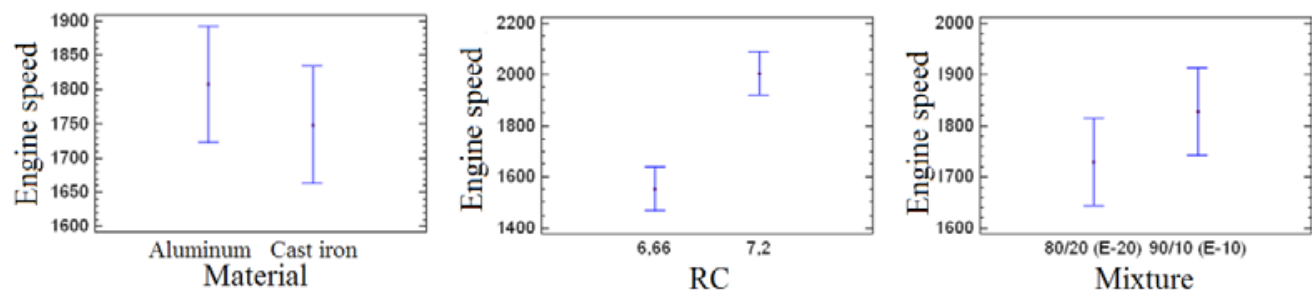

Fig. 2 Plots of engine speed means for the experimental factors studied.
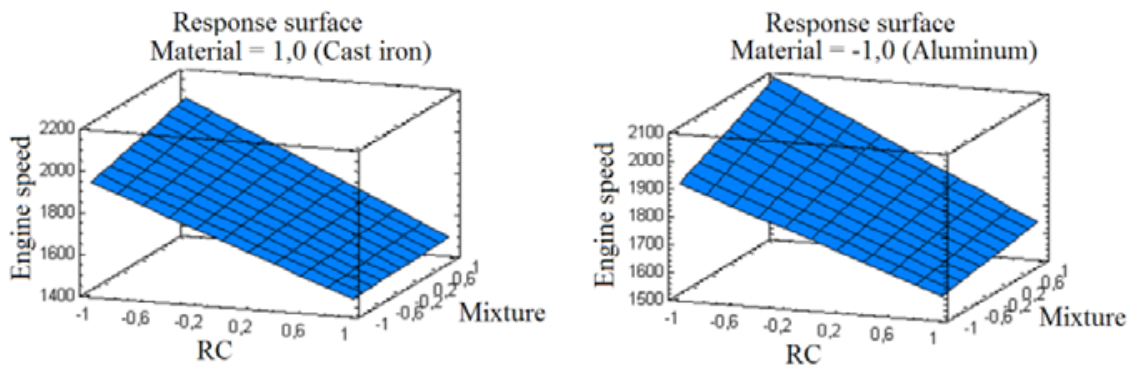

Fig. 3 Engine speed response surfaces for the experimental factors studied.

\section{Carbon monoxide analysis}

It follows from the analysis of variance, shown in Table VI and from the Pareto chart obtained, that the contributions of all the three factors studied are of the same order. Also, the influence of the interactions on the studied response is comparable to that of the main factors. This makes it difficult to isolate the influence of each of the factors involved. No conclusion can be made from the data collected as to a noticeable difference between the $\mathrm{CO}$ emissions responses to the changes performed in the controlled values of the experiment, except that their relative importance is comparable, with a very slight advantage in favor of the the compression ratio influence.

TABLE VI

ANALYSIS OF VARIANCE FOR CO EMISSIONS

\begin{tabular}{|l|c|c|c|c|c|}
\hline & $\begin{array}{c}\text { Sum of } \\
\text { Squares }\end{array}$ & DoF & $\begin{array}{c}\text { Mean } \\
\text { Squares }\end{array}$ & $\begin{array}{c}\text { F- } \\
\text { Ratio }\end{array}$ & $\begin{array}{c}\text { P- } \\
\text { Value }\end{array}$ \\
\hline A:Material & 3,60461 & 1 & 3,60461 & 18,46 & 0,1456 \\
\hline B: CR & 4,48501 & 1 & 4,48501 & 22,96 & 0,1310 \\
\hline $\begin{array}{l}\text { C:Flue } \\
\text { blend }\end{array}$ & 2,40901 & 1 & 2,40901 & 12,33 & 0,1766 \\
\hline AB & 1,08781 & 1 & 1,08781 & 5,57 & 0,2552 \\
\hline AC & 0,714013 & 1 & 0,714013 & 3,66 & 0,3068 \\
\hline BC & 0,825612 & 1 & 0,825612 & 4,23 & 0,2882 \\
\hline Total Error & 0,195313 & 1 & 0,195313 & & \\
\hline
\end{tabular}

Response surfaces of the $\mathrm{CO}$ emissions as functions of the compression ratio and fuel blends at fixed cylinder head material showed a linear dependency between $\mathrm{CO}$ emissions levels and ethanol content in the fuel blend. In general, from the response surfaces, it can be concluded that with the cast iron cylinder head the $\mathrm{CO}$ emissions levels are higher than with the aluminum one. This could be attributed to the reduction of the cylinder head heat transfer, that generates a reduction in the volumetric efficiency, and consequently in the air content of the mixture.

\section{Carbon monoxide analysis}

From the values in the analysis of variance, Table VII, and Pareto chart, it can be pointed out the major effect the compression ratio has on the $\mathrm{CO} 2$ emissions, followed by the cylinder head material, and the interaction between these two factors. The means plots, allowed to conclude the higher mean $\mathrm{CO} 2$ emissions level produced with the higher compression ratio (a near $32 \%$ increase in the emissions of $\mathrm{CO} 2$, by shifting the compression ratio from 6,6 to 7,2 ).

TABLE VII ANALYSIS OF VARIANCE FOR CO2 EMISSIONS

\begin{tabular}{|l|c|c|c|c|c|}
\multicolumn{7}{|c}{ ANALYSIS OF VARIANCE FOR CO2 EMISSIONS } \\
& $\begin{array}{c}\text { Sum of } \\
\text { Squares }\end{array}$ & DoF & $\begin{array}{c}\text { Mean } \\
\text { Squares }\end{array}$ & $\begin{array}{c}\text { F- } \\
\text { Ratio }\end{array}$ & $\begin{array}{c}\text { P- } \\
\text { Value }\end{array}$ \\
\hline A:Material & 1,97011 & 1 & 1,97011 & 13,77 & 0,1676 \\
\hline B: CR & 52,071 & 1 & 52,071 & 363,85 & 0,0333 \\
\hline $\begin{array}{l}\text { C:Flue } \\
\text { blend }\end{array}$ & $6,6125 \mathrm{e}-3$ & 1 & $6,6125 \mathrm{e}-3$ & 0,05 & 0,8652 \\
\hline AB & 8,46661 & 1 & 8,46661 & 59,16 & 0,0823 \\
\hline AC & $5,61125 \mathrm{e}-2$ & 1 & $5,61125 \mathrm{e}-2$ & 0,39 & 0,6439 \\
\hline BC & $8,61125 \mathrm{e}-2$ & 1 & $8,61125 \mathrm{e}-2$ & 0,60 & 0,5800 \\
\hline Total Error & 0,143112 & 1 & 0,143112 & & \\
\hline
\end{tabular}

The increased emissions of $\mathrm{CO} 2$ are due to a better combustion. E10 and E20 fuel blends are nearly identical in terms of $\mathrm{CO} 2$ emissions means under the idle operating

13 $^{\text {th }}$ LACCEI Annual International Conference: "Engineering Education Facing the Grand Challenges, What Are We Doing?" July 29-31, 2015, Santo Domingo, Dominican Republic 
conditions studied, and without making changes to engine calibration settings. At these conditions, fuel properties such as the laminar flame speed and heat of vaporization can counteract the energy content in a fuel, as indicated by the heating value, to reduce the $\mathrm{CO} 2$ emissions.

The $\mathrm{CO} 2$ emissions means responses described the predominant linear influence of the compression ratio on the $\mathrm{CO} 2$ emissions, with a steeper slope for the aluminum material, meaning the sensitivity of the emissions to the changes in the thermal properties of the combustion chamber materials. Likewise for $\mathrm{CO}$, the lower emission levels of $\mathrm{CO} 2$ take place for the aluminum cylinder head.

\section{E. Hydrocarbon emissions analysis}

The analysis of variance for hydrocarbons is shown in Table 8. Significant differences in the output variable are observed for the compression ratio factor, followed in sequence by the cylinder head material and the interaction of these two factors.

TABLE VIII

\begin{tabular}{|l|c|c|c|c|c|}
\multicolumn{7}{|c|}{ ANALYSIS OF VARIANCE OF HYDROCARBON EMISSIONS } \\
\hline & $\begin{array}{c}\text { Sum of } \\
\text { Squares }\end{array}$ & DoF & $\begin{array}{c}\text { Mean } \\
\text { Squares }\end{array}$ & $\begin{array}{c}\text { F- } \\
\text { Ratio }\end{array}$ & $\begin{array}{c}\text { P- } \\
\text { Value }\end{array}$ \\
\hline A:Material & $1,6524 \mathrm{e} 6$ & 1 & $1,6524 \mathrm{e} 6$ & 31,79 & 0,1117 \\
\hline B: CR & $8,21509 \mathrm{e} 6$ & 1 & $8,21509 \mathrm{e} 6$ & 158,06 & 0,0505 \\
\hline $\begin{array}{l}\text { C:Flue } \\
\text { blend }\end{array}$ & $2,82816 \mathrm{e} 5$ & 1 & $2,82816 \mathrm{e} 5$ & 5,44 & 0,2578 \\
\hline AB & $8,48364 \mathrm{e} 5$ & 1 & $8,48364 \mathrm{e} 5$ & 16,32 & 0,1545 \\
\hline AC & $2,89446 \mathrm{e} 3$ & 1 & $2,89446 \mathrm{e} 3$ & 0,06 & 0,8525 \\
\hline BC & $8,61263 \mathrm{e} 3$ & 1 & $8,61263 \mathrm{e} 3$ & 0,17 & 0,7539 \\
\hline Total Error & $5,19757 \mathrm{e} 4$ & 1 & $5,19757 \mathrm{e} 4$ & & \\
\hline
\end{tabular}

Pareto chart confirmed the strong influence of the compression ratio on $\mathrm{HC}$ emissions. Unlike the Pareto chart trend for $\mathrm{CO} 2$ emissions, the fuel composition exerts some influence on the unburned $\mathrm{HC}$ emissions levels. Increasing the ethanol content in the fuel, $\mathrm{HC}$ emissions decrease considerably at idle conditions.

Unlike the effects on $\mathrm{CO}$ and $\mathrm{CO} 2$ emissions, the increase of the compression ratio traduces into a reduction of the $\mathrm{HC}$ emissions. The HC mean is greater for the 6,6 than for the 7,2 compression ratio value, which is explained by the combustion process improvement, the reduction of crevice area and volume of the combustion chamber. With the aluminum cylinder head the mean amount of $\mathrm{HC}$ is lower than with the cast iron one. HC mean is slightly higher for the E20 fuel blend. It is difficult to draw a conclusion from the compression ratio and cylinder head material interaction, though some explanation may lay on the particularities of combustion and cleaning-up of the additional volume created to reduce the compression ratio, where the spark ignition is inserted.

HC emissions response surfaces as functions of the compression ratio and fuel blends at fixed cylinder head material showed steeper slopes for the cast iron cylinder head as compared to those of the aluminum ones.

\section{F. Warm-up analysis}

The variation of the engine temperature during the warmup period, after the engine start, for all the tests carried during the experiment, is ploted in Figure 4. The warm-up period, defined here as the time required to reach the target temperature of $75^{\circ} \mathrm{C}$, is displayed in the Table IX.

It is important to point out the elevated the cylinder head temperatures reached in the tests corresponding to the cast iron cylinder head in combination with the higher value of the compression ratio.

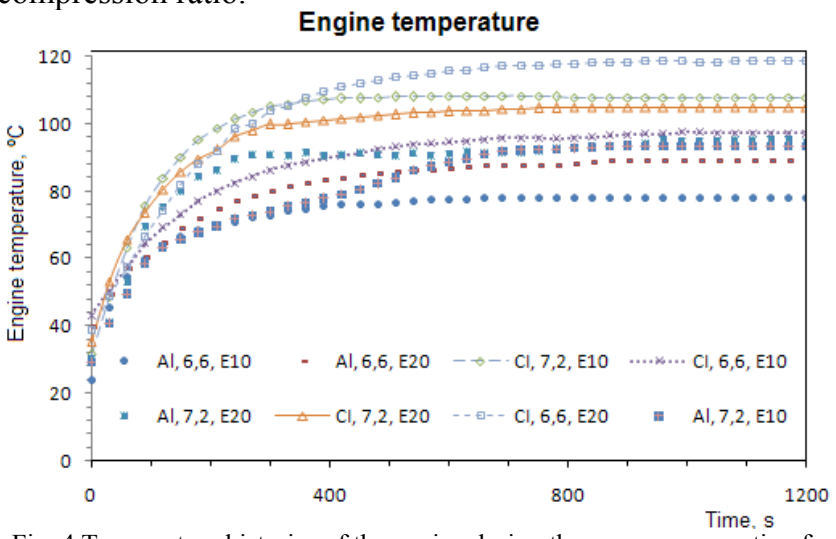

Fig. 4 Temperature histories of the engine during the warm-up operation for all the combinations of the experiment.

TABLE IX

SUMMARY OF THE TIME REQUIRED TO REACH THE ENGINE TARGET TEMPERATURE FOR ALL THE COMBINATIONS OF THE TEST PERFORMED DURING THE EXPERIMENT

\begin{tabular}{|c|c|c|c|}
\hline Test number & Time, $\mathrm{t}_{75^{\circ} \mathrm{C}}, \mathrm{min}$ & Test number & Time, $\mathrm{t}_{75^{\circ} \mathrm{C}}, \mathrm{min}$ \\
\hline $1(\mathrm{Al}, 6,6, \mathrm{E} 10)$ & 6 & $5(\mathrm{Al}, 7,2, \mathrm{E} 20)$ & 1,9 \\
\hline $2(\mathrm{Al}, 6,6, \mathrm{E} 20)$ & 3,65 & $6(\mathrm{CI}, 7,2, \mathrm{E} 20)$ & 2,1 \\
\hline $3(\mathrm{CI}, 7,2, \mathrm{E} 10)$ & 1,5 & $7(\mathrm{CI}, 6,6, \mathrm{E} 20)$ & 1,7 \\
\hline $4(\mathrm{CI}, 6,6, \mathrm{E} 10)$ & 2,85 & $8(\mathrm{Al}, 7,2, \mathrm{E} 10)$ & 5,4 \\
\hline
\end{tabular}

As was expected, the steady state temperature is lower for the tests with aluminum cylinder head, because of its higher thermal conductivity $(\mathrm{K} \approx 170 \mathrm{~W} / \mathrm{m} \bullet \mathrm{K})$ as compared to that of cast iron $(\mathrm{K} \approx 80,2 \mathrm{~W} / \mathrm{m} \bullet \mathrm{K})$.

The analysis of variance for engine warm-up time is shown in Table 10. Though no significant differences in the warm-up time are observed for the varied factors, it can be seen that the most influencing factor is the cylinder head material, followed by the fuel blend. The Pareto chart obtained confirmed the relative importance of the cylinder head material.

TABLE X

ANALYSIS OF VARIANCE OF ENGINE WARM-UP TIME

\begin{tabular}{|l|c|c|c|c|c|}
\multicolumn{1}{|c|}{ ANALYSIS OF VARIANCE OF ENGINE WARM-UP TIME } \\
\hline \begin{tabular}{|l|c|c|c|} 
Sum of \\
Squares
\end{tabular} & $\begin{array}{c}\text { D. of } \\
\text { F. }\end{array}$ & $\begin{array}{c}\text { Mean } \\
\text { Squares }\end{array}$ & $\begin{array}{c}\text { F- } \\
\text { Ratio }\end{array}$ & $\begin{array}{c}\text { P- } \\
\text { Value }\end{array}$ \\
\hline A:Material & 1,36125 & 1 & 1,36125 & 1,29 & 0,4590 \\
\hline B: CR & 5,12 & 1 & 5,12 & 4,87 & 0,2708 \\
\hline $\begin{array}{l}\text { C:Flue } \\
\text { blend }\end{array}$ & 9,68 & 1 & 9,68 & 9,21 & 0,2027 \\
\hline AB & 0,045 & 1 & 0,045 & 0,04 & 0,8701 \\
\hline AC & 0,0245 & 1 & 0,0245 & 0,23 & 0,7137 \\
\hline BC & 3,51125 & 1 & 3,51125 & 3,34 & 0,3187 \\
\hline Total Error & 1,05125 & 1 & 1,05125 & & \\
\hline
\end{tabular}

$13^{\text {th }}$ LACCEI Annual International Conference: "Engineering Education Facing the Grand Challenges, What Are We Doing?" July 29-31, 2015, Santo Domingo, Dominican Republic 
The more sluggish $(6,3625 \mathrm{~min})$ to warm-up was the combination corresponding to the aluminum cylinder head, 6,6 compression ratio value, and E10 fuel blend. The engine warmed faster, 1,7375 min, with the cast iron cylinder head, 7,2 compression ratio value, and E20 fuel blend.

\section{CONCLUSIONS}

This research focused on a serial production small single cylinder gasoline engine for non-road applications, modified for running with two cylinder heads of different materials, one insert to modify the compression ratio, and two different ethanol-gasoline blends. The engine warm-up time, fuel consumption, change in engine speed, and emissions have been tested and compared. The test measured engine warm-up performance via cylinder head temperauture measurements, and quantified the engine performance in terms of engine speed increase at idle.

Based on the analysis of the response surface plots of the experiment, optimal sets of conditions for the engine studied under idle operating conditions have been summarized and displayed in Table XI.

TABLE XI

\begin{tabular}{|c|c|c|c|c|c|}
\hline \multicolumn{2}{|c|}{ OPTIMIZATION OF THE RESPONSE VARIABLES } \\
\hline $\begin{array}{c}\text { Response } \\
\text { variable }\end{array}$ & \multicolumn{2}{|c|}{ Material } & $\begin{array}{c}\text { Comp. } \\
\text { ratio }\end{array}$ & $\begin{array}{c}\text { Fuel } \\
\text { blend }\end{array}$ & Value \\
\hline $\begin{array}{c}\text { Fuel } \\
\text { consumption } \\
\text { per cycle, } \\
\text { ml/cycle }\end{array}$ & Minimum & Aluminum & 7,2 & E20 & 0,0041 \\
\hline $\begin{array}{c}\text { Engine speed, } \\
\text { min }^{-1}\end{array}$ & Maximum & Aluminum & 7,2 & E10 & 2089,7 \\
\hline $\mathrm{CO}, \%$ & Minimum & Aluminum & 6,6 & E10 & 0,2037 \\
\hline $\mathrm{CO}_{2}, \%$ & Maximum & Aluminum & 7,2 & E20 & 12,333 \\
\hline $\mathrm{HC}, \mathrm{ppm}^{2}$ & Minimum & Aluminum & 7,2 & E10 & 1483,5 \\
\hline
\end{tabular}

Except for the $\mathrm{CO}$ emissions, the aluminum material and the higher compression ratio favor the engine performance and emissions levels. Not so conclusive is the influence of the fuel blend.

The results showed that the compression ratio plays the larger role for engine performance. At the same operating conditions, the engine speed for the cast iron cylinder head was higher compared to the aluminum cylinder head. The engine warm-up duration was larger for aluminum cylinder head, due to larger heat losses. The conclusions drawn from the results can only be applied to the factor level considered in the analysis, and cannot be extend to other similar treatments that were not explicitly considered.

In general, the study here presented found no statistically significant difference in overall performance between E-10 and E-20, which confirms the similarities of ethanol-gasoline blends with less than twenty percent ethanol at idle operating conditions.
A further study should focus on the influences of the fuel blend, compression ratio and engine material application under load conditions (observing the combustion chamber phenomena) on the engine power output; fuel consumption and engine exhaust emissions.

\section{REFERENCES}

[1] A.Sarkar, A. Chowdhuri, A. J. Bhowal, B. K. Mandal, "The Performance and Emission Characteristics of SI Engine Running on Different EthanolGasoline Blends". International Journal of Scientific and Engineering Research,Volume 3, Issue 6, June-2012.

[2] I.Gravalos, D. Moshou, T. Gialamas, P. Xyradakis, D. Kateris and Z. Tsiropoulos. "Performance and Emission Characteristics of Spark Ignition Engine Fuelled with Ethanol and Methanol Gasoline Blended Fuels". Environmental sciences, Alternative fuel, 2011. DOI: 10.5772/23176

[3] R.Waytulonis, D. Kittelson and D. Zarling. Report to the Minnesota Department of Commerce. E20 Effects in Small Non-Road SI Engines. A literature and Information Search. University of Minnesota, Center for Diesel Research, enero 15 de 2008.

[4] Orbital Engine Company. A Literature Review Based Assessment on the Impacts of a $10 \%$ and $20 \%$ Ethanol Gasoline Fuel Blend on NonAutomotive Engines. Report to Environment Australia. December, 2002.

[5] H.S. Yucesu, T. Topgul, C. Cinar, M. Okur. "Effect of ethanol-gasoline blends on engine performance and exhaust emissions in different compression ratios". Applied Thermal Engineer, 26: 2272-2278. 2006.

[6] A.K. Agarwal. "Biofuels (alcohols and biodiesel) applications as fuels for internal combustion engines". Prog Energy Combust Sci Vol.33, pp. 233271.

[7] D.C. Montgomery. Design and Analysis of Experiments. John Wiley and Sons, INC. 5th edition, 2001.

[8] F.Yuksel. "The use of ethanol-gasoline blend as a fuel in an SI engine", Renewable Energy, vol. 29, pp. 1181-1191, 2004.

[9] M.M.El-Kassaby. "Effect of using differential ethanol-gasoline blends at different compression ratio on SI engine". Alexandria Engng J, Vol.32, No3, pp. 135-142.

[10] A.A. Abdel-Rahman, M.M Osman. "Experimental investigation on varying the compression ratio of SI engine working under different ethanol-gasoline fuel blends". International Journal of Energy Research, Vol.21, pp. 31-40.

[11] M. Al-Hasan. "Effect of ethanol-unleaded gasoline blends on engine performance and exhaust emission". Energy Conversion and Management, Vol.44, No9, pp. 1547-1561.

[12] K. Mukai, H. Miyazaki.”The Influence of the Combustion Chamber Head Material of a Gasoline Engine on Exhaust HC", SAE paper 2000-01-3072.

[13] ECOPETROL. Certificado de análisis biogasolinas, protocolo E20. Empresa Colombiana de Petróleos - Ecopetrol, 2011.

[14] QROTECH COMPANY. Especificaciones de producto QRO-401.

13 $^{\text {th }}$ LACCEI Annual International Conference: "Engineering Education Facing the Grand Challenges, What Are We Doing?" July 29-31, 2015, Santo Domingo, Dominican Republic 